\title{
EFFECTIVE AND EFFICIENT MODELS OF ZAKAT MANAGEMENT: NORMATIVE AND INNOVATION BASE
}

\section{MODEL MANAJEMEN ZAKAT YANG EFEKTIF DAN EFISIEN: BERBASIS NORMATIF DAN INOVASI}

\author{
J.M. Muslimin1a; \\ 1aSekolah Pascasarjana UIN Syarif Hidayatullah Jakarta, e-mail: \\ jm.muslimin@uinjkt.ac.id
}

\begin{abstract}
ABSTRAK
Penulisan artikel ini bertujuan untuk menekankan tentang perubahan pemikiran dan tradisi terhadap interprestasi zakat sebagai sebuah amalan semata. Salah satunya adalah dengan melakukan pendekatan berdasarkan filosofis normatif untuk memperkuat sistem dan model zakat yang efektif dan efisien. Efektif dan Efisiensi zakat bukan hanya sesuatu yang memalukan untuk diperjuangkan jika belum memiliki modelnya tetapi merupakan sebuah kebutuhan. Metode analisis atau pemaparan dilakukan dengan menggunakan pendekatan normatif dan metode deduktif yuridis, di gabungkan dengan pendekatan sistemik yang mengacu pada standarisasi organisasi dan model dari pergerakan social yang efektif dan efisien. Data diperoleh dari berbagai sumber dan literatur hukum Islam kemudian dikombinasikan dengan kerangka teori arsitektural untuk mengetahui model pengorganisasian yang efektif dan efisien.
\end{abstract}

Kata Kunci: Zakat, BAZNAS, UMKM, Pemberdayaan Ekonomi

\begin{abstract}
This paper wants to emphasize that traditions and thoughts that interpret zakat only as a charity process must be changed. One of them is to do a philosophical normative basic reorientation towards strengthening the system and the model of zakat which is effective and efficient. This last thing is not only an abash to strive for, but also a necessity. Exposure is done by normative and deductive juridical methods. Combined with a systemic approach that refers to the standardization of organizations and models of social movements that are effective and efficient. The data is extracted from various sources of Islamic law literature then combined with architectural framework theory to find an effective and efficient organizing model. This research is a juridical research that is qualitative, where the researcher will describe and analyze from the data and other literature related to this research in a deductive way. In conducting the analysis, the author uses two approaches: a normative juridical approach and a paralellism setting to the basic theory of efficiency and effectiveness. Thus, to propose a model of innovation based on justified norms.
\end{abstract}


Keywords: Zakat Management, Innovation, Social Empowerment, Justified Norms

Muslimin, JM. 2019. Zakat dan Pemberdayaan Usaha Mikro, Kecil dan Menengah (Kasus Badan Amil Zakat Nasional di Palopo. Jurnal Syarikah 5 (1): 31-39.

\section{INTRODUCTION}

Islam recognizes each individual as the owner of what he/she obtains through a business process in the broadest sense, and he/she has the right to exchange his property in specifically determined limits in accordance with Islamic law. According to Islam, the concept of welfare is not based on freedom of rights or unlimited individual property as it is in capitalist terms. It is also not based on joint ownership rights as they are in the sense of communist theory.

There are limitations and requirements against property rights in Islamic teachings, namely with a just system and in accordance with the rights of all involved. Individual right property is based on individual freedom, whereas cooperation is based on needs and mutual interests. Hence, there are two main principles of social system in Islam: First, no one or a group of people who are entitled to exploit others. Second, no one or group of people can separate and isolate themselves from community (Al-Fauqi, 1982). To implement the philosophical foundation, Islam suggests these instrumental core values: cooperation, social security, active role of government, prohibition of usury and the implementation of social philantropy, namely zakat (Ali, 1988).

\section{LITERATURE AND METHODE}

\section{Extensive Definition of Zakat}

In terms of etymology, zakat has several meanings, namely al-Barakah (blessing), al-nama' (growth and development), al-thaharah (holiness), alshalah (good) (Majma' al-Lughah al'Arabiyyah, 1972). Another opinion says that zakat is originated from word of $z a$ $k a-w a$. It means to grow and grow, or it means increases (Qardhawi, 1969).

According to Islamic jurisprudence (fiqh), zakat has some meanings. For example, al-Hawi was quoted by alNawawi said that zakat is name or designation to take from certain assets according to traits to be given to certain groups (Al-Nawawi, t.th). Al-Syaukani in his book Nail al-Awthar, zakat is giving part of the wealth that has reached the Nisab to the devotees, without any condition, which prohibits giving to him (Al-Syaukani, t.th).

In short, zakat is a property that must be issued so that the property will be a blessing, growing, developing and increase. Zakat is essentially two kinds, both of which have different substance, namely zakat (mal), and zakat fitr. AlQur'an states that zakat is taken of every treasure we have, at-Taubah (9): 103. The Qur'an also states that zakat is taken from every good business result and lawful, as illustrated in Al-Baqarah (2): 267. 
Classical scholars in general categorize that assets that have received zakat are: livestock, gold and silver, goods merchandise, excavation property and the last is agricultural product. But in contemporary ijtihad, one of which is currently represented by his book Yusuf Qardhawi, he detailed many once the wealth models are hit zakat, as many models and forms of wealth born of increasingly complex activities economy.

Yusuf Qardhawi, probably the most prolific Muslim scholar who wrote on contemporary zakat, divided zakat categories into nine categories; zakat of livestock, gold and silver, zakat which also includes money, zakat on trade wealth, zakat on agricultural products covering land, zakat of honey and animal production, zakat for mining goods and yields sea, zakat of investment in factories, buildings and others, zakat of services and professions and zakat of stocks and bonds. Even Yusuf Qardhawi also added marine zakat which includes pearls and others (Qardhawi, 2002).

A Muslim economist Mundzer Kahf also revealed the same thing that Islamic teachings in detail have determined, category of assets that must be issued and classified by zakat. The categories are completed with the tariff. However, the government (zakat manager) can make changes in the structure of property that must be of zakat by holding on to the existing public texts and understanding of modern reality.

The rules used by contemporary scholars in expanding the category of wealth obligatory to zakat is to rely on the general arguments. The arguments are growth and development through business or based on the developing substance of the property. Thus, some innovations on zakat categories are created.

In discussing zakat, some terminologies are urgent to be defined. Mustahik is a body or person who has the right to receive zakat. In the At Taubah verse 60 , groups are entitled to receive zakat, namely the word of Allah SWT. AlAmil (Alms Committee)

Is the person who has the authority to take care of the zakat that authority is obtained from the authorities. Because of that Allah said: al-amiluna'alaiha (zakat administrators), Allah did not say alamiluna fiha (administrators in the matter of zakat). This word means that they have some kind of authority to collect zakat from people who have the right to issue zakat and distribute it to those who have the right to receive it. Muzakki is a person or entity owned by Muslims who are obliged to pay zakat. According to Law No. 38 of 1999 concerning the management of zakat, Muzakki is a person or entity owned by Muslims who are obliged to pay zakat. Based on this understanding it is clear that zakat is not only required by individuals.

Guidelines for the implementation of zakat issued by the Ministry of Religious Affairs have provided four points of source principles or objects of zakat, namely: 1 . That zakat is found in all assets who have illat fertility, or developing, either developing by itself or developed by road farmed or traded. 2. That zakat is imposed on all types of herbs and fruits which have economic values. 3. That zakat is contained in everything issued from the bowels of the earth, which is liquid, or solid. 4. That accepted salaries, fees and services have zakat. It must be fulfilled 
(Directorate of Development of Alms and Waqf, 2003).

\section{Zakat Management and Its Regulations}

The management of zakat in contemporary Muslim countries is very diverse. There are two forms of zakat management in contemporary Muslim communities. First, obligatory zakat payment system (obligatory system) like in Saudi Arabia, Sudan, Pakistan, and Malaysia. Second, the system of voluntary payment of zakat (voluntary system) such as in Kuwait, Bangladesh, Jordan, Indonesia, Egypt, South Africa and countries where muslims are a minority or the countries which have a sharp division of secular and religious domain, like Turkey.

Dr. Yusuf Qardhawi stated that there are some underlying factors contribute to the success of zakat management: 1 . Extending the scope of obligatory zakat property based on general inference and arguments, as an internal strategy of "Fundraising". It includes visible assets and non-visible. 2. Professional management, 3. Good model of distribution.

The Qur'an implicitly mentions that state involvement in management zakat is very necessary. This is because the government is seen as having provisions more in terms of collecting and distributing zakat.

Management of zakat in Islamic fiqh, surveyed by Qardhawi (1991), as follows: First, zakat management is part from Muslim government authorities. Second, country must maintain a separate balance sheet for zakat from state revenues and other expenditures as well. Third, the government is allowed to collect zakat from all types of property. The community must submit zakat to the government as long as the government can distribute the zakat to groups which has been stipulated by the Shari'a. Fourth, the failure of the government to manage the obligation of zakat does not remove individual responsibility from zakat payment. Obligatory zakat is still must be payed as it is stipulated in sharia.

In the Indonesian context, the management of zakat initially during the colonial period and independence had a blurry picture of zakat function, because there was no payment and distribution of zakat well. Therefore, the new order government issued Law No. 38/1999 on the management of zakat in order to institutionalize zakat management. This is aimed at facilitating zakat management, thus supporting social needs for consumptive and productive as well as the beginning of the opening of public involvement.

However, the government revised Law No. 38/1999. Law No. 23/2011 was issued. The law is concerning the management of zakat in order to improve the previous law. Because Law No. $38 / 1999$ is not in accordance with development of legal needs in society. Zakat management in Indonesia is currently regulated by Law No. 23/2011.

Law number 23 of 2011 regarding zakat management stated that Zakat management aims to improve the effectiveness and efficiency of services of zakat; and to increase the benefits to realize community welfare and poverty alleviation. In line with the efforts to realize functions and roles of zakat in the welfare of society, then zakat management regulation is issued by the government. The main goal is to facilitate, and improve 
the administration and management of zakat and the role of the Amil (Zakat Agency). The enactment of the Act No. 23 of 2011 has also the spirit of accepting contemporary ijtihad based on general Islamic principles of mashlahah which will further encourage the effectiveness of zakat management, and even give birth to additional zakat laws that are not only regulating Amil (zakat agency) but also formulating assets affected by zakat.

Based on the provisions in Law No. 23 years 2011 concerning the Management of Zakat, the zakat management organization can be defined as an institution either formed by the government or the private sector that has the task of planning, implementing and coordinating activities in the collection, distribution and utilization of zakat, infaq and alms.

This zakat management organization is divided into the Central level up to the regional level, namely the Amil Zakat Agency established by the government, at the national level Badan Amil Zakat Nasional (BAZNAS), and at the regional level Badan Amil Zakat Daerah (BAZDA), namely for the provincial and district / city level. While the institution formed by the community or community organization is the Amil Zakat Institution, Lembaga Amil Zakat (LAZ).

Both organizations can form a small unit to assist their tasks, namely the Zakat Collection Unit, Unit Pengumpul Zakat (UPZ), which can be formed in restricted work units in government agencies, stateowned enterprises, regional-owned enterprises, private companies, and representatives of the Republic of Indonesia abroad and can form UPZ at the sub-district, villages or other names, and other places.

To be more detailed and to underline the important notions, it can be stated that the establishment of LAZ must be with the permission of the Minister of Religion of the Republic of Indonesia, by fulfilling the following criteria: 1) registered as an Islamic social organization that manages the fields of education, da'wah and social; 2) $b$ erbentuk legal entities; 3) got a recommendation from BAZNAS; 4) have a Shari'ah supervisor; 5) has the technical, administrative and financial capabilities to carry out its activities; 6) nonprofit; 7) has a program to utilize zakat for the welfare of the people; and 8) willing to be audited by Shari'a and finance on a regular basis . The Law no. 23 of 2011 has determined the function of zakat management organizations, namely in Article 7 stated: 1) planning the collection, distribution and utilization of zakat; 2) the implementation of the collection, distribution and utilization of zakat; 3) controlling the collection, distribution and utilization of zakat; and 4) reporting the accountability for the implementation of zakat management.

\section{Research Methods}

This research is a juridical research that is qualitative, where the researcher will describe and analyze from the data and other literature related to this research in a deductive way. The data is extracted from various sources of Islamic law literature then combined with architectural framework theory to find an effective and efficient organizing model. 


\section{RESULT AND DISCUSSION}

\section{TOWARDS EFFECTIVE AND EFFICIENT MODEL}

The implementation of the zakat system will reduce poverty and unemployment. In order to achieve that goal, the implementation of zakat economic development requires government involvement, muzakki and mustahik. All parties must care and work hard to make it happen. If not, it means the same: letting economic injustice occur. Professional management can increase the awareness of muzakki in the fulfillment of zakat.

The annulment of zakat will generate social solidarity, reduce social inequality and in turn reduce the degree of adherence in society. For this reason, the government, BAZ or LAZ must have a precise and exact database on muzakki and mustahik in their respective areas. Muzakki and mustahik maps are needed to carry out socialization and coaching, in order to foster the trust of the muzakki, mustahik, and society in general.

To achieve this goal, the following basic core values, framework of practical procedures and systematic agendas should be done. Concerning the basic core values of Zakat Management, MA Manan underlines six principles, namely:

- The principle of faith, stating that people who pay zakat are convinced that their payment is one manifestation of their religious beliefs, so if the person concerned has not paid his zakat, yet feels perfect in his worship.

- The principle of equity and justice. It describes the purpose of zakat which is more sharing fair wealth that God has given to mankind.
- Principles of productivity and maturity, emphasize that zakat is reasonable to be paid because certain properties have produced certain products. And the results (production) can only be obtained and collected after a one-year period which is a normal measure of getting results.

- The principle of reason, namely the person who is required to pay zakat is someone who is sensible and to be responsible. From here there is an assumption that people who are immature and insane, free from zakat.

- The principle of freedom, explains that zakat is only paid by people who are free and physically healthy and spiritually, who feels guilty answer for paying zakat for the benefit together. Zakat is not collected for people being punished or someone who is mentally ill.

- The principles of ethics and reasonableness state, that zakat will not be asked arbitrarily without pay attention to the consequences. It is impossible to collect, if due to collection those who pay it will suffer. (Manan, 1970).

In the management of zakat there are frameworks of practical procedure that must be followed and adhered to have succes as expected, including:

- Openness principle, zakat should be done openly and known by public.

- Voluntary principles, the collection of zakat should always be based on the voluntary principle of Muslims who handed over his zakat without any coercion or methods considered as a coercion.

- Integration principle, in running their duties and functions of managing zakat, 
it must be carried out in an integrated manner among other components. The collection, distribution and utilization of zakat must be done in integrated manner. Only focusing to collect, without meticulous step to distribute and utilize can be regarded as unprofessional conduct.

- Principle of Profesionalism, meaning that the management of zakat must be done by those who are experts in their field, both in administration, finance and mapping the concept and its implementation in order to achieve the goal of zakat accurately. It includes having ability of informatics system of knowledge to facilitate the process of mapping, designing business procedure as well as skills of empowering society.

- Principle of Independence, this principle is actually the continuation of the principle of professionalism. It is hoped that zakat management institutions can be independent and able to carry out their duties and function without the need to wait for help from other parties.

Distribution and utilization program by zakat management institutions includes assistance for humanity, economy, education, health, and da'wah whose distribution is carried out within cash and in the form of empowerment programs, among them revolving capital for economic efforts with qardhul hasan pattern.

Last but not least, some systematic agendas can be listed to be effective and efficient steps, namely:

- First, socializing zakat to various levels and circles, such as agencies government, state-owned enterprises and private companies, entrepreneurs, and other potential community groups. - Second, building public trust to the existing zakat management institution. In this framework the government together with zakat managers hold programs of orientation and training of amil zakat. The government should have also programs of procurement for civil servants employed in National Zakat Agency (BAZNAS) and Agency Amil Zakat Daerah (BAZDA).

- Thirdly, encouraging more development of zakat empowerment programs that lead on increasing productivity and living standards of mustahik.

\section{BETWEEN NORMS AND INNOVATION}

Management of zakat according to Article 3 of Law No. 23 of 2011 concerning the Management of Zakat intended that zakat can be effective and efficient, so that in the management of zakat must go through an appropriate organization.

Zakat management aims: a. improve the effectiveness and efficiency of internal services zakat management; and $b$. increase the benefits of zakat to realize community welfare and poverty reduction.

Hence the extended function and meaning of Amil should be reformulated. Amil zakat is, those who carry out all activities of zakat, starting from collectors to the treasurer, and the guards, also from the registrar to the counter record zakat in and out, and share with the people of mustahik. God provides a part for them from zakat assets. Al-Quran pays attention to the groups.

All this shows that zakat in Islam is not only a task given to someone. But it is also state duty. The state must regulate 
and appoint people who work in the alms business consists of collectors, storage, writers, counters etc. Zakat has a special budget issued from it the salaries of the executors.

Amil zakat has various kinds assignments and jobs. All related to regulation of zakat. That is a census of people who are obliged to pay zakat and the types of zakat that are required to him. Also the amount of property that must be of zakat, then know the mustahik zakat. How many are they, how much they need and how much they can afford sufficient and other matters that are affairs which needs to be handled perfectly by experts and officers and assistants. Moreover, the new approach towards the duties is needed. Some new and updated models of organizing zakat are always necessary.

At present, zakat management can divided into two main matters, namely, affairs zakat collectors, and the distribution of zakat. Zakat collectors carry out work of zakat collection. Their task resembles a task tax collectors today. Between the task is that he conducts a census of people who are obliged to pay zakat, the kind of property they have, and the amount of property that must be of zakat. Then charge it from the obligatory zakat. Then save and keep it, to then be handed over to the dividing board of zakat. In every place and area there needs to be a branch the affairs of zakat takers. Zakat distribution officer, his affairs are closer to what is done by social department today. This business is in charge tp choose the best way to know the zakat mustahik, then carry out classifications of them and declare their rights. Also calculate the amount of their needs and the amount of costs that are sufficient for them. Finally, laying a healthy foundation in the distribution of zakat, according to the number and social conditions. Here again, such new and updated approach of statistics and informatics system of knowledge is needed.

\section{CONCLUSION AND IMPLICATION}

In order to built an effective and efficient organization model in zakat, some points can be underlined: (1) Amil zakat is those who help the government in Islamic/Muslim countries or who get permission or are chosen by organization that are recognized by the Government or Islamic community to collect and distribute zakat and other matters related to it, such as raising awareness about the law of paying zakat, seeking mustahik, collect, transform, save, invest zakat. The organization and zakat committees formed are part of the Zakat Institution mentioned in the Islamic Law . Therefore, the zakat officer must really fulfill the provisions of the Zakat Management Law . (2) The tasks entrusted to the zakat officer are those which are empowering (because they relate to the main tasks and leadership). The conditions that must be fulfilled by someone zakat officer are: Islam, men, honest, knowing the law of zakat, as well as the criteria of fqh. Other responsibilities of supporting zakat officers can be entrusted to people who do not meet the criteria above. (3) The zakat officers have the right to get a share of zakat from Amil quota given by the party who appoints them with a note that the portion does not exceed the minimum wage and that the quota does not exceed one eighth (1/8) of zakat (12.5\%). It should be noted, it is not permissible to 
appoint employees more than necessary. other. A zakat officer is not allowed to accept bribes, gifts or grants in the form of money or goods. (4) Complete the building and administration of the zakat organisation with the necessary facilities. If this facility can not be met from the state budget or from a philanthropist, then it can be taken from the Amil quota at a minimum, with a note that the facility must be closely related to the collection, storage and distribution of zakat or related to the increase in the amount of zakat. It can be also equipped by systematic program of informatics and mapping muzakki and mustahik. This kind of knowledge and skill is necessary and not in contast to the principles of Islamic norms. (5) Efficient must always be quantitative and can be measured, while effective also contains qualitative understanding. Effectively leads to achieving goals. Efficient use of inputs (input) will result in higher productivity, which is the goal of every organization in any field of activity. Including the organization of zakat.

\section{DAFTAR PUSTAKA}

Ismail L. al-Fauqi, Tawhid: Its Implication for Thought and Life, (Wahsinton DC:
The International Institute of Islamic Thuoght, 1982), p. 206-204

M. Daud Ali, Islamic Economic System of Zakat and Waqf, (Jakarta: UI Press, 1988), p. 9.

Majma' al-Lughah al-'Arabiyyah, alMu'jam alWashith, (Egypt: Dar al-Ma'arif, 1972, p. 396.

Manan, MA.

Yusuf Qardhawi, Fiqh al-Zakat, (Beirut: Dar al-Irsyad, 1969), p. .38

Abu Zakariyah Mahyu al-Din bin Syaraf alNawawi, al-Majmu 'Syarah alMuhazzab Volume V (Beirut: Dar alFikr, t.th), p. 325.

Al-Syaukani, Nail al-Authar, Volume IV, (Cairo: Mustafa al-Babi al-Halabi, t.th.), p. 129.

Directorate of Development of Alms and Waqf of the Directorate General of Islamic Guidance and Organizing of Ministry of Religion Hajj, Guidelines for Zakat Management, (Jakarta: Ministry of Religion, 2003), p.

Mundzer Kohf, op.cit, p. 37

Yusuf al-Qardawi, Fiqh al-Zakat, (Beirut: Muassasah al-Risalah, 1991), p. 126 